\title{
Phytoestrogenic Compounds and Their Synthetic Analogs, Contrary to Estradiol- $17 \beta$ Stimulates Human Derived Female Cultured Bone Cells in Hyperglycemic Conditions
}

\author{
D. Somjen ${ }^{1}$, S. Katzburg, S. Tamir ${ }^{2}$, O. Sharon, D. Hendel ${ }^{3}$ and Y. Vaya ${ }^{2}$
}

${ }^{1}$ Institute of Endocrinology, Metabolism and Hypertension, Tel-Aviv Sourasky Medical Center; Tel-Aviv 64239, and the Sackler Faculty of Medicine, Tel-Aviv University, Tel-Aviv, Israel

${ }^{2}$ Laboratory of Human Health and Nutrition Sciences, MIGAL-Galilee Technology Center, Kiryat- Shmona 11016

${ }^{3}$ Department of Orthopedic Surgery, Shaarei- Zedek Medical Center, Jerusalem, Israel

\begin{abstract}
Cultured female- derived human osteoblasts (hObs) responded by different parameters to the phytoestrogens: daidzein (D), glabrene (Gla) and glabridin (Glb), to their synthetic derivatives; carboxy-daidzein (CD) and to estradiol$17 \beta\left(E_{2}\right)$. Since the skeletal protective effects of estrogens are not discernible in diabetic women, we tested the effects of these compounds on hObs grown in growth medium with high glucose (HG; $9.0 \mathrm{~g} / \mathrm{L} ; 44 \mathrm{mM})$ compared to normal glucose (NG; $4.5 \mathrm{~g} / \mathrm{L} ; 22 \mathrm{mM}$ ) using the stimulation of creatine kinase specific activity (CK) and ${ }^{3}[\mathrm{H}]$ thymidine incorporation into DNA (DNA) as hormonal responsiveness markers. HG slightly increased DNA and CK in hObs. Stimulations by $E_{2}$ was abolished and by $c D$ and $D$ was slightly decreased in $H G$, but not by $G l a$ and $G l b$ in both age groups. Growing hObs in HG upregulated the expression of mRNA of both ER and ER $\beta$ in cells from pre- but not from post-menopausal women. Cells from both age groups express also mRNA for 25 hydroxy vitamin $D_{3} 1-\alpha$ hydroxylase and showed enzymic activity which were down-regulated by HG in both age groups. Whether Gla and $\mathrm{Glb}$ act differentially via ERs and/or 1- $\alpha$ hydroxylase is not yet established.Since these compounds are active even in $\mathrm{HG}$, they might be used for treating hyperglycemic/diabetic women.
\end{abstract}

Keywords: Human derived bone cells; Hyperglycemia; Estradiol$17 \beta$; Phytoestrogens; DNA synthesis; Creatine kinase

\section{Introduction}

We have previously studied the effects of estrogens on bone in a rat model [1-3] using the increase in the specific activity of creatine kinase as a response marker. The brain type $(\mathrm{BB})$ isoenzyme of creatine kinase (CK) which is part of the "energy buffer" system, regulates the cellular concentration of ATP and ADP, is the major component of the " $\mathrm{E}_{2}$ induced protein" of rat uterus [4] and is an efficient response marker to detect activity of $\mathrm{E}_{2}$ as well as other estrogenic compounds, in bone cells in vivo and in vitro $[1,5]$ which contain low concentrations of $\mathrm{E}_{2}$ receptors [6,7]. Notably, the stimulation of CK in cultured bone cells, correlated with increased DNA synthesis in bone, requires the higher end of the physiological range of estrogen concentrations $[1,5]$.

Estrogen is well known for its beneficial effect in osteoporosis [8]. Osteoporosis is characterized by reduction in bone mineral density, with the result of fracture after minimal trauma. The effect of estrogen in the different tissues is initiated by its binding to estrogen receptors (ERs). Two ERs have been identified, ER and ER $\beta$, which differ in their structure and tissue distribution [9]. Estrogen deficiency is known to be involved in osteoporosis [10], which affects every third woman above the age of 65 . Although estrogen treatment is efficient in preventing bone loss, it can also stimulate the growth of estrogen-dependent tumors. Hence, new compounds, which can replace current hormone replacement therapy treatments with no such deleterious effects, are highly desirable [11].

In human- derived cultured osteoblasts (hObs), we found that $\mathrm{E}_{2}$ increased cell proliferation and CK specific activity in a gender specific manner [12] as a response marker for hormonal treatment beyond estrogen itself in cells containing the relevant receptors.

Phytoestrogens are heterogenous group of plant-derived compounds some of which are selective estrogen receptor modulators (SERMs). All phytoestrogens are polyphenolic compounds with structural similarities to natural and synthetic estrogens; however they bind to the estrogen receptors with much lower affinity than $\mathrm{E}_{2}$ [13]. Soybeans and soy foods are the most significant dietary sources of the isoflavone class of phytoestrogens, which includes genistein, daidzein and biochainin A $[14,15]$ and have estrogenic action on bone and the cardiovascular system but have anti-estrogenic action on breast cancer [16].

Diabetes has been associated with a net loss of bone [17,18], with reduction of new bone formation and decreased bone mineral density. In diabetic mice the up-regulation of specific transcription factors is attenuated, resulting in deficiency in conversion of mesenchymal cells to osteoblasts $[17,18]$.

In the present study we analyzed the effects of high glucose on the response to phytoestrogens and their synthetic derivatives of humanderived cultured bone cells, which is relevant at least to some of the important factors existing in diabetes. The compounds we analyzed were the licorice derived compounds glabrene (Gla) and glabridin (Glb) [19], the carboxy-derivative of daidzein $(\mathrm{cD})[20]$ and the phytoestrogen from soy the daidzein $(D)$ [21] similar to the synthetic derivatives of $D$ the DT56a (femarelle) [22].

*Corresponding author: Dalia Somjen PhD, Institute of Endocrinology, Metabolism and Hypertension, Tel-Aviv Sourasky Medical Center, 6 Weizman St. Tel-Aviv, 64239 Israel, Tel: 9723 6973812; Fax: 9723 6973421; E-mail: dalias@ tasmc.health.gov.il

Received January 06, 2011; Accepted March 07, 2011; Published March 12 2011

Citation: Somjen D, Katzburg S, Tamir S, Sharon O, Hendel D, et al. (2011) Phytoestrogenic Compounds and Their Synthetic Analogs, Contrary to Estradiol$17 \beta$ Stimulates Human Derived Female Cultured Bone Cells in Hyperglycemic Conditions. J Steroids Hormon Sci 2:105. doi:10.4172/2157-7536.1000105

Copyright: ( $) 2011$ Somjen D, et al. This is an open-access article distributed under the terms of the Creative Commons Attribution License, which permits unrestricted use, distribution, and reproduction in any medium, provided the original author and source are credited. 
Citation: Somjen D, Katzburg S, Tamir S, Sharon O, Hendel D, et al. (2011) Phytoestrogenic Compounds and Their Synthetic Analogs, Contrary to Estradiol- $17 \beta$ Stimulates Human Derived Female Cultured Bone Cells in Hyperglycemic Conditions. J Steroids Hormon Sci 2:105. doi:10.4172/2157-7536.1000105

Page 2 of 6

\section{Materials and Methods}

\section{Reagents}

All reagents used were analytical grade. Estradiol-17 $\beta\left(\mathrm{E}_{2}\right)$, daidzein (D) and the creatine kinase (CK) assay kit were purchased from Sigma Chemicals Co. (St. Louis, MO). Carboxy-D (cD) was synthesized by us [20], licorice products: Gla and Glb were produced by us [19].

\section{Cell cultures}

Human bones were obtained from biopsies of patients undergoing corrective surgery following accidental injury, hip or knee replacement. All patients (women and men) were healthy, non-osteoporotic and not receiving hormonal replacement treatment. Three groups were defined: Pre-menopausal women, ranging between $37-55$ years old, $(n=5)$. Post-menopausal women, ranging between 60- 84 years old, $(n=5)$. The non-enzymic method for isolation and culture of human bone cells and their characterization as osteoblasts was described previously [12]. Briefly, samples of the trabecular surface of the iliac crest or long bones were cut into $1 \mathrm{~mm}^{3}$ pieces and extensively and repeatedly washed with phosphate buffered saline (PBS) to remove blood components. The explants, with no enzymatic digestion, were seeded in $100 \mathrm{~mm}$ diameter tissue culture dishes and incubated in DMEM medium without $\mathrm{Ca}^{++}$(to avoid fibroblastic growth [12], containing $10 \%$ fetal calf serum (FCS) and antibiotics. Cell outgrowth from the bone explants was apparent after 6-10 days. First passage cells were seeded at a density of $3 \times 10^{5}$ cells per $35 \mathrm{~mm}$ tissue culture dish in phenol red free DMEM with $10 \%$ charcoal stripped FCS and incubated at $37^{\circ} \mathrm{C}$ in $5 \% \mathrm{CO}_{2}$. To obtain "high glucose" (HG) conditions, the medium including the FCS, was supplemented with glucose up to a final concentration of $44 \mathrm{nM}(9.0 \mathrm{gm} /$ liter). Glucose concentration in the regular medium (NG) was $22 \mathrm{nM}$ (4.5gm/liter).

\section{Hormonal treatment}

At sub-confluence cells were treated with $30 \mathrm{nM} \mathrm{E}_{2}, 300 \mathrm{nM} \mathrm{cD}$, Gla or $\mathrm{Glb}$ and $\mathrm{D}$ at $3 \mu \mathrm{M}$ for $24 \mathrm{~h}$, followed by harvesting for CK or for DNA synthesis assays.

\section{Creatine kinase (CK) extraction and assay}

Cells were scraped off the culture dishes and homogenized by freezing and thawing three times in cold isotonic extraction buffer [12]. Supernatant extracts were obtained by centrifugation at $14000 \mathrm{xg}$ for $5 \mathrm{~min}$ at $4^{\circ} \mathrm{C}$ in an Eppendorf micro- centrifuge. Creatine kinase specific activity (CK) was measured in a Kontron Model 922 Uvicon Spectrophotometer at $340 \mathrm{~nm}$ using a Sigma coupled assay kit (procedure $47-\mathrm{UV}$ ). Protein was assayed by Coomassie brilliant blue dye binding, using BSA as the standard [12].

\section{Assessment of DNA synthesis}

Cells were grown until sub- confluence and then treated with various hormones as indicated for CK. Twenty-two hours later $\left[{ }^{3} \mathrm{H}\right]$ thymidine was added for $2 \mathrm{~h}$. Cells were then treated with $10 \%$ ice-cold trichloroacetic acid (TCA) for $5 \mathrm{~min}$ and washed twice with 5\% TCA and then with cold ethanol. The cellular layer was dissolved in $0.3 \mathrm{ml}$ of $0.3 \mathrm{~N} \mathrm{NaOH}$, samples were aspirated and $\left[{ }^{3} \mathrm{H}\right]$ thymidine incorporation into DNA was determined [23].

\section{Competitive binding assay for membrane estrogen binding activity}

Cells were cultured in 24 -well plates $\left(4 \times 10^{5}\right.$ cells/well) for $48 \mathrm{~h}$ and washed once with ice-cold binding medium (DMEM $+0.1 \%$ BSA and
25mM HEPES, pH 7.4) using reaction conditions as described previously [21]. Subsequently, cells were incubated for $90 \mathrm{~min}$ at $4^{\circ} \mathrm{C}$ with either of the steroid protein conjugates (estradiol 6-carboxymethyl-oxime; $\mathrm{E}_{2}$ -

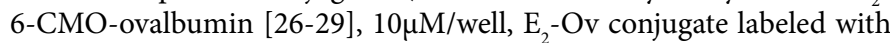
Europium $(1: 1000,200 \mu \mathrm{l}$ in binding medium) were then added and the incubation was continued for another 60 minutes at $4^{\circ} \mathrm{C}$. Binding was terminated by four successive washes with ice-cold binding medium. Enhancement solution $(300 \mu \mathrm{l} /$ well $)$ was then added to the cells, and the samples $(200 \mu \mathrm{l})$ were collected for fluorescence determination using an Arcus time resolved fluorometer (Wallac, Turku, Finland) [21, 23, 24]. Specific binding was defined as total binding of Europium protein conjugates minus binding in the presence of a 500 folds excess of conjugated estrogenic compounds or $\mathrm{E}_{2}$ where appropriate.

\section{Competitive binding assay for intracellular estrogen binding activity}

Cells grown, cultured and washed as described above, were incubated for $60 \mathrm{~min}$ at $37^{\circ} \mathrm{C}$ with ${ }^{3}[\mathrm{H}] \mathrm{E}_{2}$ with or without excess of different unlabelled estrogenic compounds. Binding was terminated by four successive washes with ice-cold binding medium, and cellular content of ${ }^{3}[\mathrm{H}] \mathrm{E}_{2}$ was measured in a Packard tricarb scintillation counter [21]. Specific binding was defined as the total binding of ${ }^{3}[\mathrm{H}]$ $\mathrm{E}_{2}$ minus binding in the presence of a 500 folds excess of free estrogenic compounds.

\section{Determination of mRNA for ER $\alpha$ and ER by real time PCR}

RNA was extracted from cultured human bone cells, shown previously [28] to contain ER $\alpha$ and $\operatorname{ER} \beta$ by western blot analysis [5], and subjected to reverse transcription as previously described [20]. For ERa, we used $5 \mu \mathrm{l}$ of cDNA in the reaction mixture with the primers 5' AATTCTGACAATCGACGCCAG 3' (forward) and 5' GTGCTTCAACATTCTCCCTCCTC 3' (reverse). For ER $\beta$, the same amount of cDNA was used with the primers 5' TGCTTTGGTTTGGGTGATTGC 3' (forward) and 5' TTTGCTTTTACTGTCCTCTGC 3' (reverse). The reaction was carried out for 30 cycles at $94^{\circ} \mathrm{C}$, for $30 \mathrm{sec}$ at $58^{\circ} \mathrm{C}$ and at $72^{\circ} \mathrm{C}$ for $1 \mathrm{~min}$; ERa and ER $\beta$ CDNA were used as standard controls and compared to RNAse $\mathrm{P}$ as internal control for mRNA.

\section{Determination of mRNA for 25 hydroxy vitamin $D_{3}$ 1-a hydroxylase (1-OHASe) by real time PCR}

Total RNA from cultured hOB was extracted using the Trizol Reagent (Gibco). An aliquot of $1 \mu \mathrm{g}$ RNA from each sample was reverse transcribed (RT) using Advantage RT for PCR kit (Clonthec), as previously described [25]. 1-OHase mRNA levels were analyzed using the ABI 7700 sequence detection system. Amplification of its CDNA was performed in $25 \mu \mathrm{l}$ of the sample on 96 wells plates in a reaction buffer containing Taqman universal PCR master kit. The sequences of nucleotides were as follows; forward primers: CACCCGACACGGAGCCTT; reverse primers: TCAACAGTGGACACAAACA; Taqman probe: TCCGCGCTGTGGGCTCGG. RNAse P expression served as an internal control for each sample and was performed by an assay on demand gene expression products, which consists of a 20x mixture of unlabeled PCR primers and Taqman MGB probe labeled with 5 carboxy fluorescein (FAM) dye. Measurements were performed in triplicates. The PCR conditions were: $50^{\circ} \mathrm{C}$ for $2 \mathrm{~min}, 95^{\circ} \mathrm{C}$ for $15 \mathrm{sec}$ and $60^{\circ} \mathrm{C}$ for $1 \mathrm{~min}$. The total volume of the reaction was $25 \mu \mathrm{l} ; 12.5 \mu \mathrm{l}$ universal master mix, $1.25 \mu \mathrm{l} 20 \mathrm{x}$ assay on demand mix and $11.25 \mu \mathrm{l}$ cDNA [25]. 
Citation: Somjen D, Katzburg S, Tamir S, Sharon O, Hendel D, et al. (2011) Phytoestrogenic Compounds and Their Synthetic Analogs, Contrary to Estradiol- $17 \beta$ Stimulates Human Derived Female Cultured Bone Cells in Hyperglycemic Conditions. J Steroids Hormon Sci 2:105. doi:10.4172/2157-7536.1000105

\section{Assesment of 25 hydroxy vitamin $D_{3} 1-\alpha$ hydroxylase activity}

25 hydroxy vitamin $\mathrm{D}_{3} 1-\alpha$ hydroxylase activity was assessed by the measurement of $1,25(\mathrm{OH})_{2} \mathrm{D}_{3}(1,25 \mathrm{D})$ generated in hObs within $60 \mathrm{~min}$ after the addition of $25(\mathrm{OH}) \mathrm{D}_{3}(200 \mathrm{ng} / \mathrm{ml})$ to culture, using $1,25 \mathrm{D}^{125} \mathrm{I}$ RIA kit from DiaSorin, Mn, USA [25]. Protein of the layer was assayed by the Bradford method.

\section{Statistical significance}

The significance of differences between experimental and control values $P$, was evaluated using a non-paired, two-tailed Student's $t$-test in which $\mathrm{n}=$ number of donors.

\section{Results}

Expression and modulation of ER $\alpha$ and ER $\beta$ in human female-derived osteoblasts by high glucose

Female- derived osteoblasts from both age groups expressed mRNA for both ER $\alpha$ and ER $\beta$ as measured by real time PCR (Figure 1). The ratio of ERa To ER $\beta$ was 121:1 in pre- and 77:1 in post-menopausal derived osteoblasts with no significant difference between the mRNA levels in both age groups. High glucose increased the expression of both $\mathrm{ER} \alpha$ and $\mathrm{ER} \beta$, in female- derived cells from both age groups with higher effect in pre-menopausal Obs (Figure 1).

Modulation of creatine kinase specic activity in response to different phytoestrogens in human female-derived osteoblasts in high glucose medium

Female derived hObs treated with $\mathrm{E}_{2}$, Gla, Glb, $\mathrm{cD}$ or D for $24 \mathrm{~h}$, showed a significant increase in CK specific activity in both age groups (Figure 2). The response of pre-menopausal cells was higher with $\mathrm{E}_{2}$ and D whereas Gla was more effective in post-menopausal osteoblasts, and no age dependent difference was observed in treatments with Glb or $\mathrm{cD}$ (Figure 2). Growing the cells in HG increased constitutive level of the specific activity of CK in pre-menopausal osteoblasts by $46 \pm 5 \%$ and in post- menopausal osteoblasts by $34 \pm 8 \%$. Growth of the cells in high glucose led to abolishment of the response of CK specific activity

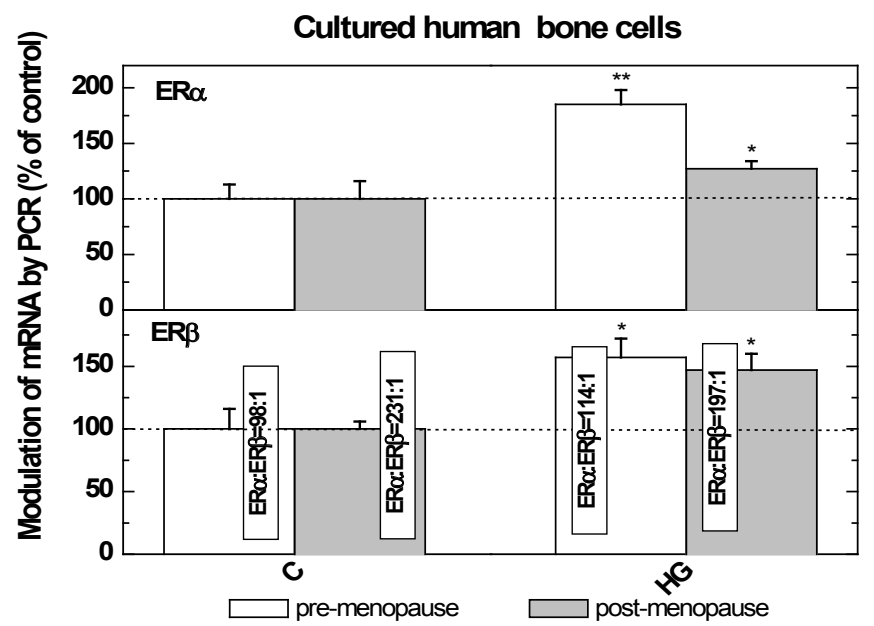

Figure 1: Modulation by hyperglycemia of the expression of mRNA for ER $\alpha$ and $E R \beta$ in primary human female- derived osteoblasts. Bone cells were obtained and cultured, and extracts prepared for real time PCR analysis as described in Materials and Methods. Results are means SEM for triplicate cultures from 5 donors for each group. Means of cells grown in high glucose (grey bars) were compared to cells grown in normal glucose (open bars): * $P<0.05$; ${ }^{* *}, P<0.01$.

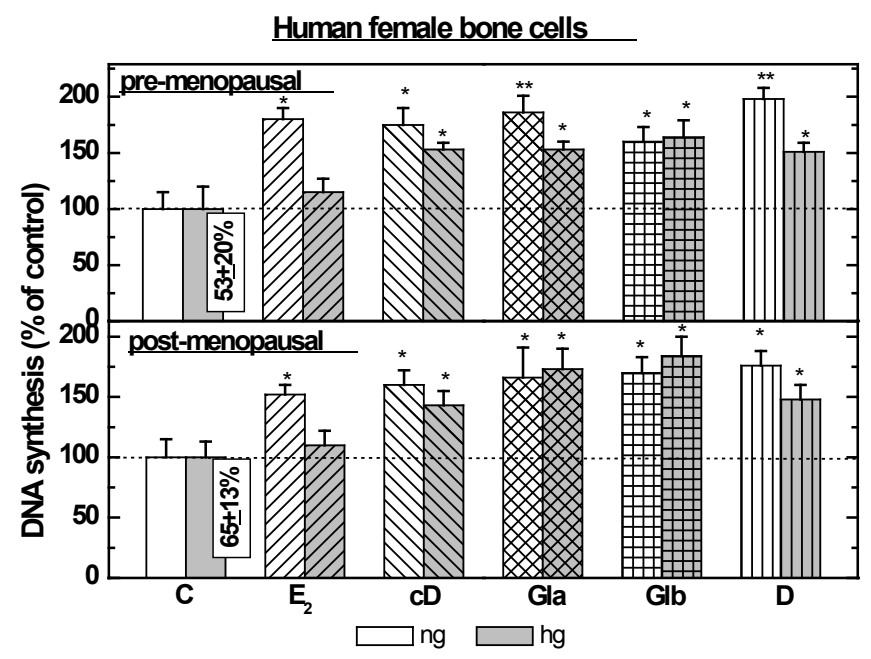

Figure 2: Stimulation of CK specific activity by different phytoestrogens and $E_{2}$ in primary bone-derived cells, from pre- and post- menopausal women, grown at different glucose concentrations; either normal (NG; $22 \mathrm{mM})$ or high (HG; $44 \mathrm{mM}$ gray bars) glucose concentrations. Bone cells were cultured, treated and assayed for CK activity as described in Materials and Methods. Cells were treated for $24 \mathrm{~h}$ with vehicle or $30 \mathrm{nM} \mathrm{E}_{2}$ or $300 \mathrm{nM}$ of $\mathrm{cD}$, Gla or Glb or $3000 \mathrm{nM}$ of $\mathrm{D}$. Results are means \pm SEM for triplicate cultures from 5 women/ group for each group. Control means of CK specific activity were 28.6 \pm 6.5 and $24.6 \pm 4.0 \mathrm{nmol} / \mathrm{min} / \mathrm{mg}$ protein, for pre- and post-menopausal women respectively. Experimental means compared to control means: * $P<0.05$; ** $P$ $<0.01 ;{ }^{* *}, P<0.001$. Means of cells at $\mathrm{HG}+$ estrogenic compounds vs. cells at NG+ estrogenic compound: \#, $P<0.05 ; \#, P<0.01$.

\section{Human female bone cells}

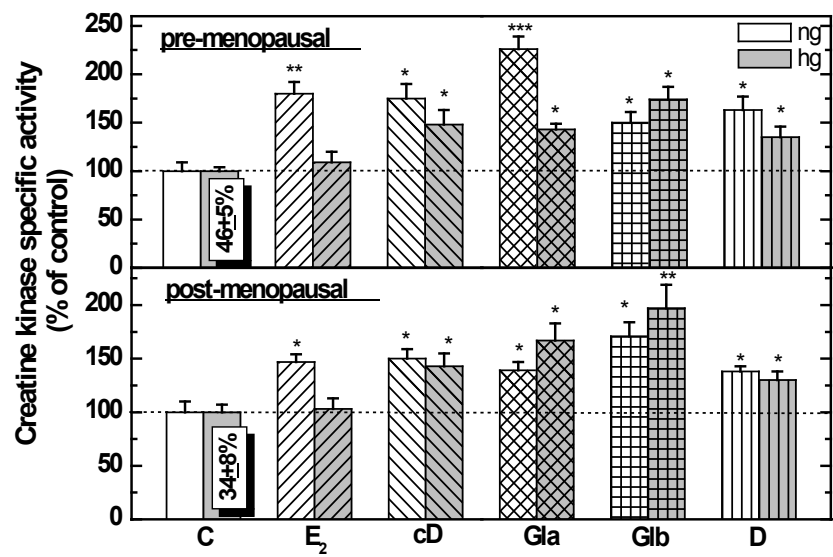

Figure 3: Stimulation of DNA synthesis by the different phytoestrogens and $\mathrm{E}_{2}$ in primary bone-derived cells from pre- and post-menopausal women, grown at different glucose concentrations either normal $(4.5 \mathrm{~g} / \mathrm{L} ; 22 \mathrm{mM}$ light) or high $(9.0 \mathrm{~g} / \mathrm{L} ; 44 \mathrm{mM}$ gray bars) glucose concentrations. Bone cells were cultured treated and assayed for CK activity as described in Materials and Methods. Cells were treated for $24 \mathrm{~h}$ with vehicle or $30 \mathrm{nM} \mathrm{E}_{2}$ or $300 \mathrm{nM}$ of $\mathrm{cD}$, Gla or Glb or $3000 \mathrm{nM}$ of D. Results are means \pm SEM for triplicate cultures from 5 women/ group for each group. Control means of CK specific activity were $3870 \pm 350$ and $3460 \pm 400 \mathrm{dpm} /$ well, for pre- and post-menopausal women respectively. Experimental means compared to control means: * $P<0.05 ; * *, P<0.01$ $\star * *, P<0.001$. Means of cells at $\mathrm{HG}+$ estrogenic compounds vs. cells at NG+ estrogenic compound: \#, $P<0.05 ; \# \#, P<0.01$.

to treatment with $\mathrm{E}_{2}$, slightly reduction in the response to $\mathrm{cD}$ or $\mathrm{D}$ but did not change the response to Gla or Glb in cells from both age groups (Figure 2). 
Citation: Somjen D, Katzburg S, Tamir S, Sharon O, Hendel D, et al. (2011) Phytoestrogenic Compounds and Their Synthetic Analogs, Contrary to Estradiol- $17 \beta$ Stimulates Human Derived Female Cultured Bone Cells in Hyperglycemic Conditions. J Steroids Hormon Sci 2:105. doi:10.4172/2157-7536.1000105

Page 4 of 6

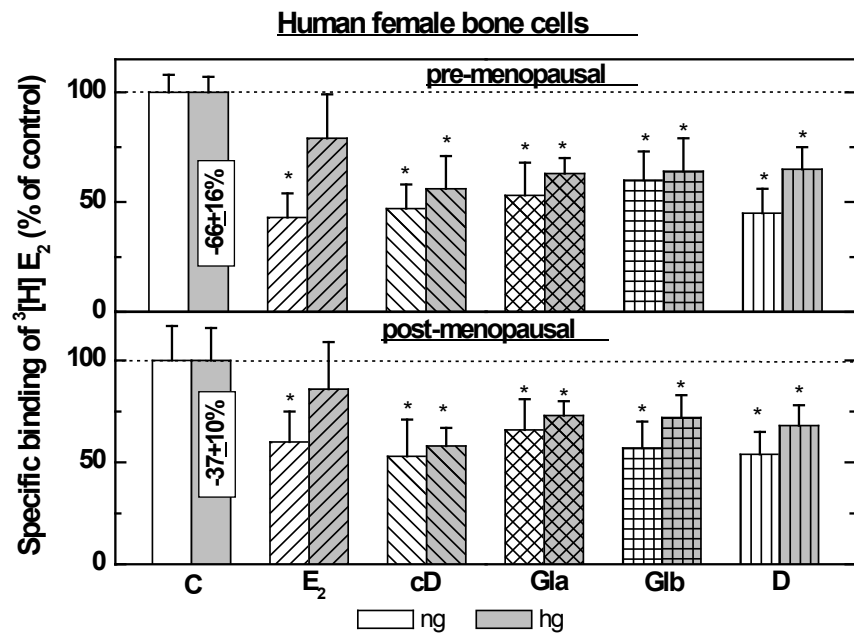

Figure 4: Modulation of the specific binding of estrogenic compounds to nuclea binding sites in primary bone-derived cells from pre- and post- menopausa women, grown at different glucose concentrations either normal (NG;22mM) or high (HG; $44 \mathrm{mM}$ gray bars) glucose concentrations. Bone cells were cultured treated and assayed for nuclear binding of ${ }^{3}[\mathrm{H}] \mathrm{E}_{2}$ as described in Materials and Methods. Results are means \pm SEM for $\%$ of specific binding of triplicate cultures in the presence of 500 fold excess concentration of the different phytoestrogens as competitors. Experimental means compared to control means: ${ }^{*}, P<0.05$.

\section{Human female bone cells}

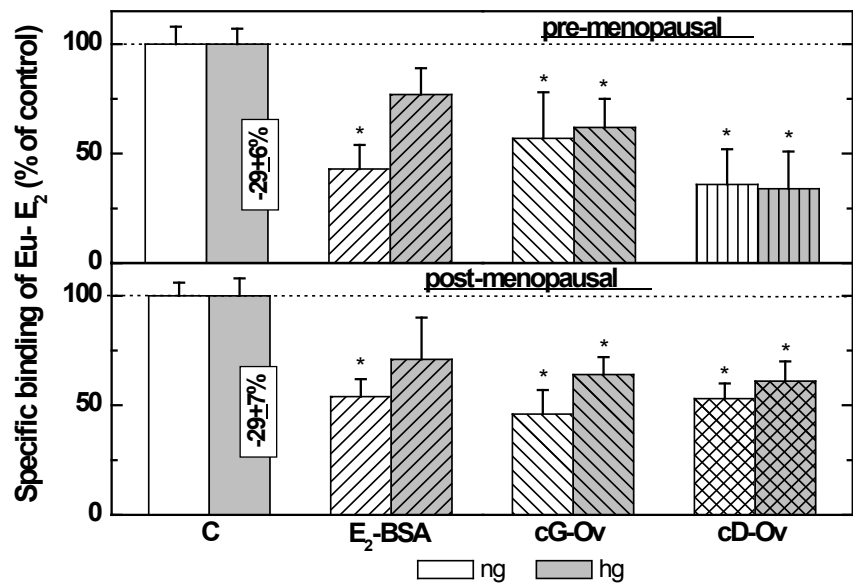

Figure 5: Modulation of the specific binding of estrogenic compounds to membranal binding sites in primary bone-derived cells from pre- and postmenopausal women, grown at different glucose concentrations either normal (NG; $22 \mathrm{mM}$ ) or high (HG; $44 \mathrm{mM}$ gray bars) concentrations. Bone cells were cultured, treated and assayed for membranal binding of Eu- Ov- $\mathrm{E}_{2}$ as described in Materials and Methods. Results are means \pm SEM for $\%$ of specific binding of triplicate cultures in the presence of 500 fold concentration of the different phytoestrogenic-protein conjugates as competitors. Experimental means compared to control means: ${ }^{*}, P<0.05$

\section{Modulation of DNA synthesis response to different phytoestrogens in human female-derived osteoblasts by high glucose}

Female- derived hObs treated with $\mathrm{E}_{2}$, Gla, Glb, $\mathrm{cD}$ and $\mathrm{D}$ for 24 $\mathrm{h}$, showed a significant increase in DNA synthesis in both age groups (Figure 3). The response of pre-menopausal cells was higher with $\mathrm{E}_{2}$ and $\mathrm{D}$ treatments whereas no age dependent difference with the other compounds (Figure 3). Growing the cells in HG increased basal level of DNA synthesis in pre-menopausal osteoblasts by $53 \pm 20 \%$ and in post- menopausal osteoblasts by $65 \pm 13 \%$. Growth of the cells in high glucose led to abolishment of the response of DNA synthesis to treatment with $\mathrm{E}_{2}$, slightly reduction in the response to $\mathrm{CD}$ or $\mathrm{D}$ but did not change the response to Gla or Glb cells from both age groups (Figure 3).

Intracellular binding of the different phytoestrogens and its modulation in human female derived- osteoblasts in high glucose medium

Both pre- and post- menopausal human female-derived osteoblasts

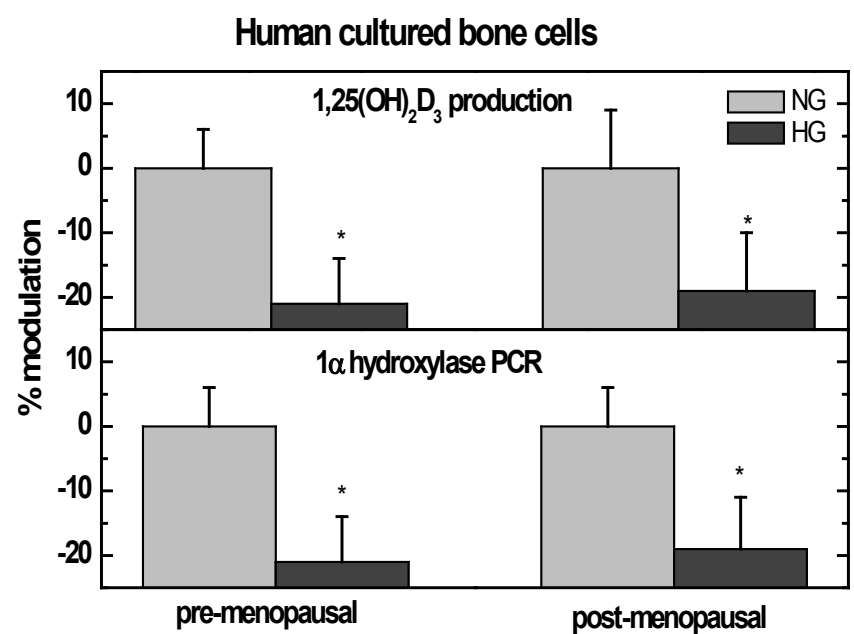

Figure 6: Modulation of the expression of mRNA for 1-OHase (lower panel) and the production of $1,25 \mathrm{D}$ (upper panel) in cultured bone cells from pre- and postmenopausal women by high glucose (HG, dark gray bars) in the growth medium compared to normal glucose (NG, light gray bars). Conditions for the different parameters and the assays are as described in Materials and Methods. Results are expressed as $\%$ change in the concentration of $1,25 \mathrm{D}$, (pg/mg protein) or in 1- OHase mRNA expression as quantified by real time PCR $(n=4-8)$. ${ }^{*}<<0.05$ ${ }^{* *} p<0.01$, compared with growth in NG.

Human female bone cells

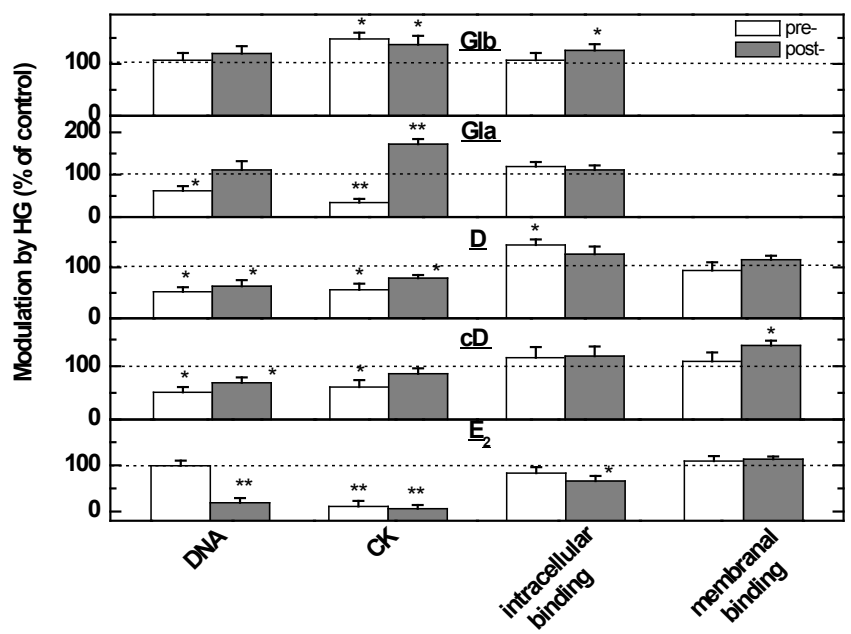

Figure 7a and 7b: Summary of the effects of HG on responses of cultured bone cells from pre- and post-menopausal women, to the different hormones on the different parameters as described in the legends to previous figs. ${ }^{*} P<0.05$ ${ }^{\star *} p<0.01$, compared with control incubates containing the vehicle for the active compound only. 
Citation: Somjen D, Katzburg S, Tamir S, Sharon O, Hendel D, et al. (2011) Phytoestrogenic Compounds and Their Synthetic Analogs, Contrary to Estradiol- $17 \beta$ Stimulates Human Derived Female Cultured Bone Cells in Hyperglycemic Conditions. J Steroids Hormon Sci 2:105. doi:10.4172/2157-7536.1000105

Page 5 of 6

(Obs) demonstrated specific binding of ${ }^{3}[\mathrm{H}] \mathrm{E}_{2}$ (Figure 4) which is competed for by the different phytoestrogens, presumably to predominantly nuclear under these conditions ( $37^{\circ}$ for $\left.60 \mathrm{~min}\right)$. All phytoestrogens tested for competition with ${ }^{3}[\mathrm{H}] \mathrm{E}_{2}$, showed significant binding in both age groups. Growing the cells in HG decreased the specific binding of $\mathrm{E}_{2}$ but not that of the other phytoestrogens in their competition of binding of ${ }^{3}[\mathrm{H}] \mathrm{E}_{2}$ in cells from both age groups (Figure 4). Also the total binding was increased by $57-66 \%$ at both age groups.

Modulation of specific membranal binding of the different phytoestrogens in human female- derived osteoblasts in high glucose medium

Growth of female derived osteoblasts from both age groups at high glucose concentration decreased total binding of $\mathrm{Eu}-\mathrm{Ov}-\mathrm{E}_{2}$ in both age groups but did not affect the competition with $\mathrm{E}_{2}-\mathrm{BSA}$ or $\mathrm{cD}-\mathrm{Ov}$ in both age groups, but the competition with $\mathrm{cD}-\mathrm{Ov}$ was decreased slightly but not statistically significant (Figure 5). Also the total binding was increased significantly by $29 \%$ at both age groups.

Expression and modulation of 25 hydroxy vitamin $D_{3} 1-\alpha$ hydroxylase in human female-derived osteoblasts in high glucose medium

Female-derived bone cells from both ages expressed mRNA for 25 hydroxy vitamin $\mathrm{D}_{3} 1-\alpha$ hydroxylase (1-OHase) as measured by real time PCR, corrected for RNAse P mRNA (Figure 6). Growing the cells in high glucose in the medium decreased the expression of 1-OHase by about 35 to $65 \%$ respectively, in both age groups.

\section{Modulation of 1, $25(\mathrm{OH})_{2} \mathrm{D}_{3}$ production in human female-} derived osteoblasts in high glucose medium

Female-derived bone cells from both age groups produced $1,25(\mathrm{OH})_{2} \mathrm{D}_{3}$ as measured by radio-immunoassay (Figure 6). Growing the cells in high glucose in the medium resulted decreased activity of 1 -OHase measured by the production of 1,25 by about $80-70 \%$ in cells from both age groups (Figure 6).

\section{Discussion}

The estrogenic compounds tested in our studies can be divided roughly into two classes on the basis of their age dependent stimulation of DNA synthesis and CK specific activity in primary cultures of human female derived-osteoblast. Similarly to $\mathrm{E}_{2}, \mathrm{D}$ showed higher stimulation in pre-menopausal than in post-menopausal cells (Figures 2 and 3). On the other hand cD, D, Gla, Glb showed similar stimulations in cells from pre- or post-menopausal women (Figures 2 and 3). Growing the cells in high glucose concentration $(44 \mathrm{mM}$ instead of $22 \mathrm{mM})$ sharpens the ability to distinguish between the groups. First of all, the hyperglycemia increased the constitutive levels of DNA by $53-65 \%$ respectively and of CK by $46-34 \%$ (Figures 2 and 3). Moreover, the stimulation of DNA and $\mathrm{CK}$ by $\mathrm{E}_{2}$ was abolished by hyperglycemia in both age groups, the stimulation of DNA and CK by $\mathrm{CD}$ and $\mathrm{D}$ was slightly decreased by hyperglycemia in both age groups, while the effects of Gla and Glb were not significantly changed by hyperglycemia in either age group (Figures 2 and 3). It is important to note that the constitutive levels of DNA synthesis and CK specific activitybwere increased by hyperglycemia in age group bone cells (Figures 2 and 3).In order to understand the mechanism of the changes induced by hyperglycemia in the present study, we show that the abolition of estrogenic stimulation by hyperglycemia occurs in our non-transformed human-derived primary osteoblasts, was accompanied in contrast, by increases in mRNA levels of ER $\alpha$ and to less extent in ER $\beta$ in female cells at both ages (Figure 1).
We also analyzed total cellular (mainly nuclear) and membranal estrogen binding in the different cells. While in normal hObs, the phytoestrogens tested, were bound to both nuclear and membranal sites, with no age-dependent difference in the binding. This parallels our previous findings $[21,23,24]$ using human vascular smooth muscle cells. Attempt to correlate estrogen receptors mRNAs with the changes in nuclear and/or membrane binding failed also in these vascular cells $[21,23,24]$.

The high glucose abolished nuclear binding (Figure 4 ) of $\mathrm{E}_{2}$ but not the phytoestrogenic compounds tested are parallel to the decreased responsiveness by growth in high glucose (Figures 2 and 3) but opposite to the increases in ERs mRNA (Figure 1). Also the membranal binding of $\mathrm{E}_{2}$, as well as the other phytoestrogens tested was not affected by hyperglycemia (Figure 5). Membranal binding is therefore not correlated with the abolishment of DNA synthesis and CK specific activity stimulated by $\mathrm{E}_{2}$ and the slight reduction of the stimulations by some of the phytoestrogens used in hyperglycemia (Figure 7a and b). This indicates that membranal mediated pathways are not involved in DNA and CK stimulation by estrogenic compounds tested in this study and others [24] as it is mainly nuclear receptor mediated. This finding is in accordance with our previous finding that impermeable proteinbound hormones were unable to stimulate $\mathrm{CK}$ in human vascular smooth muscle cells in the manner that $\mathrm{E}_{2}$ and phytoestrogens do, but they bind to membranal binding sites $[21,23,24]$.

When we assayed the changes in ERs mRNA expression by real time PCR, while ER $\alpha$ and ER $\beta$ mRNA were found in both ages of female-derived bone cells at higher abundance of ERa, hyperglycemia increased ER $\alpha$ and ER $\beta$ expression in female-derived cells (Figure 1).

The modulation of ERs is a recent addition to the spectrum of changes induced by hyperglycemia $[21,23,24]$, which stimulates the differentiation of osteoblasts and osteoclasts and stimulates osteoblasts to produce osteocalcin and alkaline phosphatase.

Bone growth in diabetes which is disturbed [17,28] is also not enhanced to the same extent by hormone replacement therapy [26] and might be the result of lower hip BMD in young women due to their type 1 diabetes [27]; therefore the use of the specific phytoestrogens and their synthetic derivatives that we use in this study, might provide an alternative solution. Further studies in this direction in animal models have to be conducted for this purpose.

\section{References}

1. Somjen D, Weisman Y, Harell A, Berger E, Kaye AM (1989) Direct and sex specific stimulation by sex steroids of creatine kinase activity and DNA synthesis in rat bone. Proc Natl Acad Sci U S A 86: 3361- 3363

2. Somjen D, Weisman Y, Mor Z, Harell A, Kaye AM (1991) Regulation of proliferation of rat cartilage and bone by sex steroid hormones. $\mathrm{J}$ Steroid Biochem Mol Biol 40: 717-723.

3. Kaye A M, Weisman Y, Harell A, Somjen D (1990) Hormonal stimulation of bone cell proliferation. J Steroid Biochem Mol Biol 37: 431- 435.

4. Reiss N, Kaye AM (1981) Identification of the major component of the estrogen induced protein of rat uterus as the BB isozyme of creatine kinase. J Biol Chem 256: $5741-5749$.

5. Fournier B, Haring S, Kaye AM, Somjen D (1996) Stimulation of creatine kinase specific activity in human osteoblast and endometrial cells by estrogens and anti-estrogens and its modulation by calciotropic hormones. J Endocrinol 150 : 275-285.

6. Eriksen EF, Colard DS, Berg NJ, Graham ML, Mann KG, et al. (1988) Evidence of estrogen receptors in normal human osteoblast- like cells. Science 241: 8486. 
Citation: Somjen D, Katzburg S, Tamir S, Sharon O, Hendel D, et al. (2011) Phytoestrogenic Compounds and Their Synthetic Analogs, Contrary to Estradiol- $17 \beta$ Stimulates Human Derived Female Cultured Bone Cells in Hyperglycemic Conditions. J Steroids Hormon Sci 2:105. doi:10.4172/2157-7536.1000105

7. Komm BS, Terpening CM, Benz DJ, Graeme KA, Kox M, et al. (1988) Estrogen binding, receptor mRNA, and biological response in osteoblast- like osteosarcoma cells. Science 241: 81-84

8. Manolagas SC, Kousteni S, Jilka RL (2002) Sex steroids and bone. Recent Progr Horm Res 57: 385-409.

9. Enmark E, Gustafsson JA (1999) Oestrogen receptors - an overview. J Intern Med 246: 133-138.

10. Delmas PD (2000) Treatment of postmenopausal osteoporosis. Lancet 359 2018- 2026.

11. Miksicek RJ (1994) Interaction of naturally occurring non-steroidal estrogens with expressed recombinant human estrogen receptor. J Steroid Biochem Mol Biol 49: 153-160.

12. Katzburg S, Ornoy A, Hendel D, Lieberherr M, Kaye AM, et al. (2001) Age and gender specific stimulation of creatine kinase specific activity by gonadal steroids in human bone-derived cells in culture. J Endocrin Invest 24: 166- 172.

13. Setchell KD, Lydeking-Olsen E (2003) Dietary phytoestrogens and their effect on bone: evidence from in vitro and in vivo, human observational, and dietary intervention studies. Amer J Clin Nutr 78: 593S-609S.

14. Brzezinski A, Debi A (1999) Phytoestrogens: the "natural" selective estrogen receptor modulators? J Obstet Gynecol Reprod Biol 85: 47-51.

15. Tham DM, Gardner CD, Haskell WL (1998) Potential health benefits of dietary Phyto-estrogens: A review of the clinical, epidemiological, and mechanistic evidence. J Clin Endocrinol Metab 83: 2223- 2235.

16. Morabito N, Crisafulli A, Vergara C, Gaudio A, Lasco A, et al. (2002) Effects of genistein and hormone-replacement therapy on bone loss in early postmenopausal women: a randomized double-blind placebo-controlled study. J Bone Miner Res 17: 1904-1912.

17. He H, Liu R, Desta T, Leon C, Gerstenfeld LC, et al. (2004) Diabetes causes decreased osteoclastogenesis, reduced bone formation and enhanced apoptosis of osteoblastic cells in bacteria stimulated bone loss. Endocrinology 145: 447-452.

18. Katzburg S, Lieberherr M, Ornoy A, Klein BY, Hendel D, et al. (1999) Isolation and hormonal responsiveness of primary cultures of human bone-derived cells: gender and age differences. Bone 25: 667-673.
19. Somjen D, Katzburg S, Vaya J, Kaye AM, Hendel D, et al. (2004) Estrogenic activity of glabridin and glabrene from licorice roots on human osteoblasts and prepubertal rat skeletal tissues. J Steroid Biochem Mol Biol 91: 241-246.

20. Somjen D, Zaltsman Y, Gayer B, Kulik T, Knoll E, et al. (2002) 6-Carboxymethy genistein: A novel selective oestrogen receptor modulator (SERM) with unique differential effects on the vasculature, bone and uterus. J Endocrinol 173: 415427.

21. Somjen D, Kohen F, Lieberherr M, Gayer B, Schejter E, et al. (2005) Membrana effects of phytoestrogens and carboxy derivatives of phytoestrogens on human vascular and bone cells: New insights based on studies with carboxy-biochanin A. J Steroid Biochem Mol Biol 93: 293- 303.

22. Somjen D, Katzburg S, Sharon O, Hendel D, Yoles I (2011) DT56a (Femarelle), contrary to estradiol-17 $\beta$, is effective in human derived female osteobl asts in hyperglycemic condition. J Steroid Biochem Mol Biol 123: 25-29.

23. Somjen D, Kohen F, Gayer B, Sharon O, Limor R, et al. (2004) Role of putative membrane receptors in estradiol on human vascular cell growth. Amer Hyperten 17: 462- 469

24. Somjen D, Paller CJ, Gayer B, Kohen F, Knoll E, et al. (2004) High glucose blocks estradiol's effects on human vascular cell growth: differential interaction with estradiol and raloxifene. J Steroid Biochem Mol Biol 88: 101-110.

25. Somjen D, Katzburg S, Stern N, Kohen F, Sharon O, et al. (2007) 25 Hydroxy- vitamin $D_{3}-1 \alpha$ Hydroxylase expression and activity in cultured human osteoblasts and their modulation by parathyroid hormone, estrogenic compounds and dihydrotestosterone. J Steroid Biochem Mol Biol 107: 238-244.

26. Effects of menopause and estrogen replacement therapy or hormone replacement therapy in women with diabetes mellitus: Consensus opinion of The North American Menopause Society. (2000) Menopause 7: 87-95

27. Liu EY, Wactawaski- Wende J, Donhaue RP, Dmochowski J, Hovey KM, et al. (2003) Does low bone mineral density start in post- teenage years in women with type 1 diabetes? Diabetes Care 26: 2365-2369.

28. Somjen D, Katzburg S, Sharon O, Kaye AM, Gayer B, et al. (2004) Modulation of response to estrogens in cultured human female bone cells by a noncalcemic Vitamin $D$ analog: changes in nuclear and membranal binding. $J$ Steroid Biochem Mol Biol 89-90: 393-395. 